\title{
The degree of structural protection at the edge $\beta$-strands determines the pathway of amyloid formation in globular proteins
}

\author{
Gemma Soldi $^{1}$, Francesco Bemporad ${ }^{1}$, Fabrizio Chiti ${ }^{1, *}$. \\ ${ }^{1}$ Dipartimento di Scienze Biochimiche, Università di Firenze, Viale Morgagni 50, 50134 Firenze, Italy
}

* To whom correspondence should be addressed: e-mail: fabrizio.chiti@unifi.it; tel. +39-055-4598319; fax: +39-055-4598905. 


\begin{tabular}{|c|c|c|c|c|c|c|c|c|c|c|c|}
\hline protein & $\begin{array}{l}\text { Continuous } \\
\text { H-bonding }\end{array}$ & $\begin{array}{c}\text { Covering } \\
\text { loop }\end{array}$ & $\beta$-bulges & Prolines & $\begin{array}{c}\text { Inward pointing } \\
\text { charge }\end{array}$ & $\begin{array}{c}\text { Sheet edge } \\
\text { rolls in }\end{array}$ & $\begin{array}{l}\text { Very } \\
\text { short }\end{array}$ & $\begin{array}{c}\text { Very twisted } \\
\beta \text {-strand }\end{array}$ & $\begin{array}{l}\text { L } \beta \text { Gly bend, } \\
\text { reverse twist }\end{array}$ & $\begin{array}{c}\text { Switch between } \\
\text { sheets }\end{array}$ & $\begin{array}{c}\text { Number of } \\
\text { protections }^{\mathrm{b}}\end{array}$ \\
\hline $\mathrm{mAcP}$ & $\begin{array}{l}\text { none } \\
\text { none }\end{array}$ & $\begin{array}{l}\text { none } \\
\text { none }\end{array}$ & $\begin{array}{c}\text { 75-76, 82-83 } \\
\text { none }\end{array}$ & $\begin{array}{l}\text { none } \\
\text { none }\end{array}$ & $\begin{array}{c}\text { Glu83 } \\
\text { Arg23, Glu27 }\end{array}$ & $\begin{array}{l}\text { none } \\
\text { none }\end{array}$ & $\begin{array}{l}\text { no } \\
\text { yes }\end{array}$ & $\begin{array}{l}\text { none } \\
\text { none }\end{array}$ & $\begin{array}{l}\text { none } \\
\text { none }\end{array}$ & $\begin{array}{l}\text { none } \\
\text { none }\end{array}$ & $\begin{array}{l}3 \\
3\end{array}$ \\
\hline HypF-N & $\begin{array}{l}\text { none } \\
\text { none }\end{array}$ & $\begin{array}{l}\text { none } \\
\text { none }\end{array}$ & $\begin{array}{c}\text { 71-72 } \\
\text { N none o }\end{array}$ & $\begin{array}{l}\text { Pro78 } \\
\text { none }\end{array}$ & $\begin{array}{l}\text { Arg76 } \\
\text { Glu87 }\end{array}$ & $\begin{array}{l}\text { none } \\
\text { none }\end{array}$ & $\begin{array}{l}\text { no } \\
\text { yes }\end{array}$ & $\begin{array}{l}\text { none } \\
\text { none }\end{array}$ & $\begin{array}{l}\text { none } \\
\text { none }\end{array}$ & $\begin{array}{l}\text { none } \\
\text { none }\end{array}$ & $\begin{array}{l}3 \\
2\end{array}$ \\
\hline AcPDro2 & $\begin{array}{l}\text { none } \\
\text { none }\end{array}$ & $\begin{array}{l}\text { none } \\
\text { none }\end{array}$ & $\begin{array}{c}\text { 75-76?, 82-83 } \\
\text { No }\end{array}$ & $\begin{array}{l}\text { none } \\
\text { none }\end{array}$ & $\begin{array}{l}\text { No } \\
\text { No }\end{array}$ & $\begin{array}{l}\text { none } \\
\text { none }\end{array}$ & $\begin{array}{l}\text { no } \\
\text { yes }\end{array}$ & $\begin{array}{l}\text { none } \\
\text { none }\end{array}$ & $\begin{array}{l}\text { none } \\
\text { none }\end{array}$ & $\begin{array}{l}\text { none } \\
\text { none }\end{array}$ & $\begin{array}{c}1-2 \\
1\end{array}$ \\
\hline Sso AcP & $\begin{array}{l}\text { none } \\
\text { none }\end{array}$ & $\begin{array}{l}\text { none } \\
\text { none }\end{array}$ & $\begin{array}{l}\text { 81-82 } \\
\text { none }\end{array}$ & $\begin{array}{l}\text { none } \\
\text { none }\end{array}$ & $\begin{array}{l}\text { No } \\
\text { No }\end{array}$ & $\begin{array}{l}\text { none } \\
\text { none }\end{array}$ & $\begin{array}{l}\text { no } \\
\text { yes }\end{array}$ & $\begin{array}{l}\text { none } \\
\text { none }\end{array}$ & $\begin{array}{l}\text { none } \\
\text { none }\end{array}$ & $\begin{array}{l}\text { none } \\
\text { none }\end{array}$ & $\begin{array}{l}1 \\
1\end{array}$ \\
\hline
\end{tabular}

